\title{
КОМПОНЕНТ ХРОНОТОПУ В РОМАНАХ ЮРІЯ АНДРУХОВИЧА ТА ТАДЕУША КОНВІЦЬКОГО
}

\author{
Віктор Яручик \\ Волинський національний університет імені Лесі Українки \\ ORCID: 0000-0002-9314-944X
}

\begin{abstract}
Анотація. Часопростір у романах Юрія Андруховича та Тадеуша Конвіцького є явищем багатовимірним. Він має національну, метафізичну, соціально- та культурно-історичну, індивідуально-психологічну, географічну складові. Тадеуш Конвіцький в часових рамках одного дня передав суспільні настрої цілої країни протягом багатьох років. Вміло застосовуючи різні прийоми гри з часом: актуалізацією суб'єктивної пам'яті, ретроспекціями і посиланнями до історичного минулого, спогадами, розтягуванням i, навпаки, стисненням часових рамок. Потрібно звертати увагу на хронотоп з усіма його складниками, тобто на хронотопний комплекс, крім часу і простору, це - людина, рух, дорога, мета, характер руху. Зважаючи на потенційну схожість ідейного задуму і його формального вираження у романах Малий апокаліпсис Т. Конвіцього і Московіада Ю. Андруховича, особливості хронотопів також будуть схожими. Основне ціннісно-емоційне навантаження в романах мають хронотопи порогу, зустрічі та дороги.
\end{abstract}

Ключові слова: Конвіцький, Андрухович, часопростір, хронотоп, проза, роман

Літературно-культурні зв'язки Польщі та України впродовж останніх десятиліть є дуже тісними і вимагають своїх прискіпливих дослідників. Митці обох сусідніх слов'янських держав перебувають у полі спільних літературних зацікавлень. Особливо цікавими для аналізу хронотопу надаються яскраві представники сучасних літературних традицій Польщі та України: Тадеуш Конвіцький і Юрій Андрухович. Хронотоп романів Малий апокаліпсис та Московіада є художнім відображенням світобачення пізнього Т. Конвіцького і раннього Ю. Андруховича. Категорія хронотопу у романах є малодослідженою, а то й взагалі не розкритою. Цим зумовлений наш інтерес до цієї теми. 
Дослідженням творчості Тадеуша Конвіцького та Юрія Андруховича займалися Тамара Гундорова ${ }^{1}$, Олексій Кискін ${ }^{2}$, Лілія Лавринович ${ }^{3}$, Оксана Забужко ${ }^{4}$, Пьотр Жбіковський ${ }^{5}$ Валерія Чайковська ${ }^{6}$, Марина Гогуля ${ }^{7}$, Роман Магдиш ${ }^{8}$.

За влучним зауваженням Нонни Копистянської: «у кожного автора $\epsilon$ своя система і манера настроювання читача на певний тон, починаючи із заголовка, епіграфа, перших слів тексту»9.

Заголовок роману Т. Конвіцького Малий апокаліпсис стосується поняття «апокаліпсис», яке походить з грецької мови і означає «одкровення, відкриття». Цей термін також є назвою останньої книги Нового Завіту, де було представлено бачення кінця світу та сповіщення про пришестя Христа знову. У свою чергу, розмовною мовою «апокаліпсис» визначає жахливі таємничі явища, які віщують якийсь кінець: світу, нації, культури тощо.

Кінець світу, як і в книзі Нового Завіту, віщують різні знаки на небі та на землі. Симптоми винищення у Малому Апокаліпсисі включають вулиці, будинки, мости, що перетворюються на руїни. Усі локуси передають повне руйнування моральних звичаїв та підрив основних цінностей.

Варто відзначити, назва роману Т. Конвіцького Малий апокаліпсис містить у собі певний «смисловий оксюморон», адже в уяві читача саме значення слова «апокаліпсис» викликає асоціацію з величезним, всесвітнім хаосом, кінцем епох, смертю всього сущого на землі і, можливо, навіть усього Всесвіту. Увесь Всесвіт, досвід поколінь, історичну пам’ять

\footnotetext{
1 Т. Гундорова, Післячорнобильська бібліотека. Український літературний постмодерн, Київ 2005.

2 О. Кискін, Урбаністичний хронотоп в постмодерністському романі: автореф. дис. На здобуття наук. ступеня канд. філол. наук, Київ 2006.

3 Л. Лавринович, Постмодернізм в украйнській, польській та російській прозі: типологія образу персонажа. Дис. кан. філол. наук, Луцьк 2002, 175 с.

4 О. Забужко, Польська «культура» $і$ ми, або Малий апокаліпсис Московіади. Хроніки від Фортінбраса. Вибрана есеїстика, Київ 2006, с. 308-318.

$5 \quad$ P. Żbikowski, Apokalipsa czy rozpad totalitarnego systemu? Wśród starych i nowych lektur szkolnych, Rzeszów 1994, 535 s.

6 В. Чайковська, «Московіада» Ю. Андруховича - не лише «Малий апокаліпсис», «Вісник Житомирського університету ім. І. Франка» 2005, вип. 20, с. 59-64.

7 М. Гогуля, Колоніальна дійсність у романі Тадеуша Конвіщького «Малий Апокаліпсис», «Проблеми слов'янознавства» 2016, вип. 65, с. 110-125.

8 Р. Магдиш, Літературна критика про специфіку часопростору сучасних твоpiв-мандрів, «Наукові записки Харківського національного педагогічного університету ім. Г. С. Сковороди» 2013, вип. 2 (2): Літературознавство, с. 83-89.

9 Н. Копистянська, Хронотоп як аспект вивчення слов'янського романтизму (на матеріалі західнослов'янських літератур у європейському контексті), Слов'янські літератури: Доповіді. ХІІ Міжнародний з'їзд славістів (Краків, 27 серпня-2 вересня 1998), Київ 1998, c. 49.
} 
T. Конвіцький поміщає у свого героя, який будучи освіченим варшавським інтелігентом, стає маленькою людиною у світі радянізованого польського простору, в якому він нещасний як людина, як громадянин, і в якому він переживає свій перший і останній судний день, свій «малий апокаліпсис», кінець того світу, який він ще колись мав надію побачити. Однак, чи є цей апокаліпсис справді таким малим і незначущим? Очевидно ні. Розчарування, хаос і суцільна руїна, яку відчуває головний герой - це спроєктована картина всього радянського світу. На відміну від біблійного Апокаліпсису, який мав космічний характер, роман Т. Конвіцького показує падіння конкретної держави та суспільства, хоча в той же час він говорить про падіння всього світу, перетворюючись на візію глобальної руйнації. Назва Малий апокаліпсис стосується передусім падіння світу головного героя, що живе в тоталітарній комуністичній системі.

Цим малим апокаліпсисом герой намагається попередити великий. А великий апокаліпсис - це національний кінець світу, кінець держави, культури, етносу, традицій та всього, що вирізняє рідне 3-поміж чужого. Саме це спостерігає герой під час своєї подорожі містом своїх розбитих надій, вдихаючи просякнуте ганебним пристосуванством повітря, чуючи усю какофонію, яка звучить на вулицях - російські частушки і звуки святкового оркестру як чужі сліди чужої культури, бачачи всяке намагання вписатися в контекст уявної дружньої інтернаціональної картинки радянського світу. Варшава у Т. Конвіцького є столицею імперії, яка зростила глухих і сліпих деміургів... «Вони роз'їлися завдяки нашому поневірянню, нашому впокоренню, нашій безіменності... Їхня велич походить із нашого добровільного здрібніння. Їхній геній виріс на наших творчих могилах» ${ }^{10}$.

Самоспалення - це спроба врятувати не тільки сенс власного життя але й ім'я нації. Така назва роману $є$ і звинуваченням, i попередженням. Бачення падіння світу в романі можна розглядати у двох вимірах. 3 одного боку, воно показує картину реальності, в якій легко розпізнати риси конкретного суспільства 3 часів комуністичного тоталітаризму. 3 іншого боку, це бачення набуває рис універсалізму, представляючи втрату основних цінностей у світі, де панує всюдисуще зло.

Дмитро Ліпскеров говорив, що «Коли-небудь людина дійде до такого ступеня розвитку, що придумає собі розвагу, на подобі Апокаліпсису. Сама собі його влаштує і Бога не попросить про допомогу. Закон не допустить Апокалипсису!» ${ }^{11}$. Саме руйнація нації зсередини і зовні виступає тут як розвага для тоталітарної системи, а людина просто ще

\footnotetext{
10 Т. Конвіцький, Малий Апокаліпсис, пер. 3 пол. Ю. Андрухович, «Всесвіт» 1991, №12, c. 10 .

11 Д. Ліпскеров, Сорок лет Чанчжоэ, Москва 2006, с. 12.
} 
один елемент цієї гри. Остання фраза звучить 3 долею сарказму. Адже апокаліпсис, малий чи великий, він поза впливом закону. Тоталітаризм на чолі з абсурдними законами думав, що влада розпоряджатися світом знаходиться тільки у їх руках, але Т. Конвіцький розвінчує цю думку.

Таким чином, назва роману актуалізовує не тільки внутрішній хронотоп героя, але й відображає зруйнований простір держави під тиском історичного часу.

У час написання цього роману проблема панування «Великого брата» і пригнічення національної гідності країн, а найгірше їх «неспротив», пристосуванство стала насущною не тільки для Польщі. Так, співзвучні проблеми пронизують роман Московіада Ю. Андруховича. Назва польського роману актуалізовує часовий компонент, а роман Ю. Андруховича - просторовий. Перед читачем постає завдання - визначити за твором територіальні межі цього простору: чи він буде географічно обмежений, чи то символічно постане у свідомості реципієнта в образі всього радянського світу.

У самій назві Московіада автор вже робить натяк на те, де і як відбуватимуться події. Це як констатація факту всюдисущості Москви, абсурдного обширу злочинної столиці світу. Простір цієї Московіади міцно засмоктав у себе різні національності, «але в тому й нещастя імперії, що вона вирішила поєднати непоєднуване - приміром, естонців 3 туркменами» ${ }^{12}$ і т.д. Він засмучений країною, у якій усі просмерділися несвободою: «Чому свободи ви лишаєте так мало, що її вистачає лише на падіння із сьомого поверху?... Імперія загравала зі свободою, гадаючи, що таким чином збереже оновленою саму себе» ${ }^{13}$.

Отто фон Ф. про смерть не думає. Він просто знаходиться у чужому місті, намагається вивчити його таємниці, звикнути до хаосу, руїни. «У цьому місті іноземців, в такій етнічній мозаїці з часом перестаєш почуватися іноземцем, чужим, бо тут усі чужі і всі іноземці» ${ }^{14}$. Українці, українство і вся наша національна спадщина «перебувала, як Йона в череві кита, в надрах виключного, всемогутнього й всюдисущого російського впливу, всихаючи з роками до якогось незрозумілого «обласного» рудимента великої російської культури» ${ }^{15}$.

Звідси можемо зробити висновок про символічне значення заголовку роману, де простір і час постають як дотикові категорії: автор прагне донести до читача певне повідомлення, яке стосується змісту всього твору, починаючи $з$ перших слів. Вже $з$ самої назви роману видно гротеск та

\footnotetext{
Ю. Андрухович, Московіада, Івано-Франківськ 2006, с. 148.

Там само, 131.

Там само, с. 181.

О. Забужко, цит. праця, с. 312.
} 
інтертексуальність. Заголовок відсилає читача до Гомерівської «Ілліади» 3 натяком на тему падіння Трої. Москва - це сучасний авторові Іліон, який взятий в облогу здеморалізованим населенням, пияками, про яких, каже автор, імперія повинна була турбуватися: «Свого часу тебе навчали, що Римська імперія загинула під ударами рабів і колонів. Ця імперія загине під ударами пияків. Колись вони всі вийдуть на Красну площу i, вимагаючи пива, рушать на Кремль... Тому імперії слід було вчасно подбати про своїх пияків. Не воювати з вітряками лібералізмів чи націоналізмів, не полювати на відьму релігійності чи на примару правозахисництва, а єдине - подбати про своїх вірних пияків. Щоб вони завше мали чим залитися. Щоб вони любили своїх потворних жінок. Щоб вони створювали собі подібних дітей. I все. Але імперія зрадила своїх пияків. I прирекла себе на розпад》 ${ }^{16}$. Таким чином, назва роману своєю інтертекстуальною грою актуалізовує часопросторовий компонент, з натяком на загибель як людини, так і імперії.

Отже, бачимо, що дослідження хронотопу даних романів можна розпочинати ще 3 їх назви, які репрезентують авторський натяк на сюжетний розвиток тексту та несуть в собі основне ідейне навантаження твору. Адже і «апокаліспис», і «московіада» (з конкретним натяком на Іліаду Гомера) посилають читачеві певний меседж, що події романів зводяться до певного кінця, загибелі і падіння.

Юрій Андрухович (нар. 1960 р.) - український поет, прозаїк, перекладач, есеїст, творчість якого знана як в Україні, так і за іiі межами. 1993 року, на сторінках часопису «Сучасність» виходить роман Московіада, який викликав хвилю як позитивної, так і негативної критики, через свою схожість з романом Малий апокаліпсис польського письменника Тадеуша Конвіцького, і переклад якого здійснив Ю. Андрухович. Зокрема О. Забужко категорично відгукнулася на твір, назвавши його Малим Апокаліпсисом, на малоросійський лад перелицьованим», у якому Ю. Андрухович просто переніс концептуальну філософсько-естетичну схему оригіналу - на систему знакових кодів іншої культури ${ }^{17}$.

В. Т. Чайковська вважає, що «текстуальна гра Ю. Андруховича 3 Т. Конвіцьким - це швидше усвідомлений прийом, а не неконтрольоване наслідування ${ }^{18}$.

Л. Лавринович зачислила роман Московіада до одного 3 «найбільш європеїзованих варіантів постмодернізму в сенсі теоретичної відповідності постмодерністським концепціям сучасності, саме тому вони, у зі-

Ю. Андрухович, Московіада, с. 137.

О. Забужко, цит. праця, с. 311

18 В. Чайковська, цит. праця, с. 60. 
ставленні $з$ творами інших письменників творять український варіант параісторичного постмодерністського дискурсу» ${ }^{19}$.

Так чи інакше, роман став помітним явищем в історії українського постмодернізму, в якому відлунюють насущні проблеми для тогочасного населення всього радянського простору.

Московіада певною мірою носить автобіографічні елементи розповіді, зважаючи на кількарічний досвід перебування поета в Москві і пізнання цього середовища зсередини. Т. Гундорова акцентує увагу на «нарцисичному» дискурсі його доробку, який має вираз у граничному центруванні художнього матеріалу творів навколо персони автора ${ }^{20}$. Письменник не заперечує такої рецепції своїх творів, зазначаючи: «Від роману до роману я просто все більше відкриваюся і все більше говорю про себе самого» ${ }^{21}$.

Ми спробуємо окреслити роль соціуму і соціального хронотопу у формуванні психології головного героя.

Людина, як істота соціальна, не може існувати поза світом, так чи

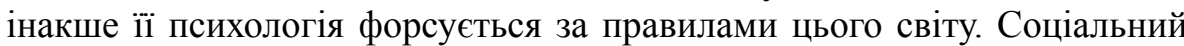
простір формує персонажа твору, позаяк цей простір детермінований і обмежений законами тоталітарної держави і її устрою.

Отто фон Ф., як і більшість молодих талантів, приїхав до Москви, однак це середовище чуже, холодне, непривітне, і «вірші його, певно, лишилися в атмосферних полях України, московські ж поля виявилися надто щільними для їхнього солов'їного проникнення» ${ }^{22}$.

Зрештою, герой $є$ представником «українського гвинтика», який підтримує роботу великої інтернаціональної, комуністичної, тоталітарної машини, яка скоро розпадеться через те, «що вона вирішила поєднати непоєднуване - приміром, естонців з туркменами». Ця країна має здатність рости на Захід, поглинаючи маленькі народи, їхні мови, звичаї, пиво, поглинаючи також великі народи.

Соціальний простір для героя Отто фон Ф. розпочинається 3 місця проживання. На початку роману автор максимально звужує, стискає простір, в якому натомість відбувається «часовий вибух». У просторі невеличкої, «совєтівської» будівлі гуртожитка - узагальнена історія чи не всього покоління: «Спиш самовіддано, найчастіше до одинадцятої, поки узбек за стіною не увімкне на повний регулятор духмяну орієнтальну музику «адин палка два струна». Проклинаючи незлостиво нещасну нашу

\footnotetext{
19 Л. Лавринович, цит. праця, с. 80.

20 Т. Гундорова, цит. праця, с. 21.

21 Ю. Андрухович, Вона робить минуле живим і незавершеним, «Коментар» 2003, № 2, c. 4 .

22 Т. Гундорова, цит. праця, с. 8.
} 
історію, дружбу народів і союзний договір 22-го року, усвідомлюєш: далі спати не можна. Тим більше, що єврей за іншою стіною вже повернувся з виправи по крамницях, вкотре накупивши, скажімо, «колготок» для своєї незліченної ветхозавітної родини з Біробіджана, для всіх колін ії. Тепер з почуттям праведно виконаного обов'язку він сяде за написання нових віршів середньовічною мовою ідиш... I всі вони будуть надруковані в часописі «Совєтіш Геймланд», як живе свідчення ненастанної державної турботи про культуру малих народів» ${ }^{23}$.

Прошарок соціуму, в якому перебуває поет Отто фон Ф., низькість якого йому доводиться споглядати кожного дня, складається з представників «літератури графоманської, спеченої за нудними рецептами великої реалістичної традиції ${ }^{24}$, які швидше нагадують ії персонажів, більшість 3 них просто принизливо обслуговують партійні інтереси. Але зрештою, в таких умовах відсутності правди знання й будь-який досвід стають непотрібними. Ю. Андрухович свідомо звертається до типово постмодерного образу бібліотеки як звалища нікому не потрібного людського досвіду, загострюючи сутність метафори: «Зрештою, будь-яка бібліотека - це велика (більша чи менша) каналізація людського духу» ${ }^{25}$.

Топос радянського гуртожитку виступає елементом національного, соціального, психологічного хронотопів, у сполученні з часопростовими характеристиками доби, цей гуртожиток $є$ відображенням як душевного, так і соціального стану його жителів.

Соціальний час і соціальний простір виступають категоріями соціального буття не тільки в сенсі опису його на духовно теоретичному рівні; вони $\epsilon$ вихідними схемами побудови звичайної поведінки людей i ïx повсякденних взаємодій ${ }^{26}$. Можливо, саме тому звичайна поведінка людей сконцентрована на аморальності, розпусті, пияцтві, адже саме так проявляється спротив зламаної, дезорієнтованої людини середовищу, яке всяко намагається тиснути, заангажовувати власну соціальну і природну свободу людини. Власне тут доречно згадати слова Готфріда Вільгельма Лейбніца, що «якби магніт мав свідомість, то він вважав би свій напрямок на північ визначенням своєї волі, законом своєї волі», що власне і намагалася зробити більшовицька влада 3 людьми - зробити з них цей магніт із заданим вектором руху думок, у якого будь-який шанс відхилитись від напрямку - це так чи інакше смерть, чи то фізична, чи моральна. Однак, як зазначає Г. Лебніц: «Якби магніт мав свідомість i, отже, волю і свободу,

Ю. Андрухович, Московіада, с. 4.

Там само, с. 24.

Там само, с. 99.

К. Бурнашов, Хронотоп - ключ к познанию социального пространства, «Вестник Нижегородского университета им. Н. И. Лобачевского» 2007, № 2 (7), с. 42-43. 
то він був би мислячим, тим самим простір був би для нього як загальний простір, який охоплює всі напрямки, і тому один напрямок на північ був б швидше обмеженням для його свободи, так само як для людини бути утримуваним на одному місці $є$ обмеженням, а для рослини - ні $\rangle^{27}$.

Можна зробити висновок, що саме від диспропорції бажаного і можливого, від розуміння приреченості соціуму, в якому живе Отто фон Ф., самогубство - це єдиний шлях досягти сласної свободи, тобто гармонії природної і громадянської свободи. А свободи в тоталітарній державі так мало, «що ï вистачає лише на падіння з сьомого поверху. Імперія загравала зі свободою, гадаючи, що таким чином збереже оновленою саму себе ${ }^{28}$.

На різних етапах історії, в різних типах соціальності проблема свободи набуває конкретної розмірності, по-своєму осмислюється. Тому в Московіад $i$, зважаючи на часовий пласт твору, соціальний часопростір $\epsilon$ еквівалентом руйнації загальнолюдських цінностей.

Часопросторова парадигма роману актуалізується також у концепті порядок - хаос, як певні категорії хронотопу. Зовнішній порядок, який пропагує імперія, протиставляється внутрішньому хаосу, дезорієнтацією громадян: «тут усі п’яні, не лише я. Це сталося через дощ. Ми всі дуже нещасні. Нещасні, жалюгідні виродки з розкоординованими рухами» ${ }^{29}$.

Відправною чи то кінцевою точкою всього цього абсурду є пивбар на Фонвізіна, «ангар для пияків», який є уособленням всієї трагічності цього часу. Ю. Андрухович за долею іронії називає парадизом, тобто раєм на землі, який насправді є осередком духовного падіння. Тут під дією алкоголю пробуджується громадянська активність людей, яка так і залишиться в стінах цього «земного раю».

Тут зустрічаються четверо представників різного типу соціальної думки, сформованої за законами часу. Всі вони висловлюють свою громадянську позицію: Цезар, який проти входження в злочинні антилюдські партії, і Боря, який інтереси цієї партії представляє і захищає, Юрко Голіцин, який дуже любить братерство-свободу-рівність, Ройтман, який щодня інформує про неіснування Бога і нарешті Отто, який виголошує свою позицію за повне й остаточне відокремлення України від Росії: «Я готовий обійняти кожного, я готовий подати руку кожному на цій землі. Бо всі люди створені, курва мать, для щастя, хоча розуміють його кожен по-своєму» ${ }^{30}$.

\footnotetext{
27 А. Максимов, И. Беляев, Целосность и свобода человека, Екатеринбург 2004, с. 85.

28 Ю. Андрухович, Московіада, с. 131

29 Там само, с. 105.

30 Там само, с. 115.
} 
В організації соціального простору важливе місце відіграє реальний соціальний хронотоп зустрічі. Зустрічі, як відомо, відбуваються в конкретний час і в конкретному місці (просторі). Будь-то зустрічі дипломатичні, творчі або побачення закоханих - всі вони породжують певні соціальні відносини, сприяють оформленню соціального простору в конкретному місці в конкретний час. Зустрічі супроводжують героя роману 3 початку його останнього дня.

3 соціальним хронотопом зустрічі тісно пов'язаний інший хронотоп - реальний хронотоп дороги. Під час мандрування відбувається переосмислення життєвих цінностей, формування світогляду, а отже, емоційний стан людини, якщо говорити про художній текст, не контролює структурування часопростору, і останній, моделюється через психологічні колізії та внутрішній стан суб〉єкта.

«На дорозі перетинаються в одній часовій і просторовій точці просторові і тимчасові шляхи різних людей - представників усіх станів, станів, віросповідань, національностей, різного віку. Тут можуть випадково зустрітися ті, хто роз'єднаний соціальною ієрархією і просторовою даллю» ${ }^{31}$. Ця точка - місце розвитку певного роду соціальних відносин, які виникли виключно з волі випадку. В Московіад $i$ - це подорож не тільки від чарки до чарки, не тільки буквальне переміщення - від станції до станції метро, від зупинки тролейбуса до зупинки, це і переміщення по іншій осі - вертикалі. Падіння із сьомого поверху гуртожитку на землю випадкового нічного гостя до нашого героя, а потім його воскресіння у мареннях головного персонажа, або ж спуск у підземелля - метро є теж символічними. Сам Ю. Андрухович у тексті свого твору стверджує, що «пияцтво - також різновид подорожі! Це подорож по звільнених півкулях свідомості, а, значить, і буття» ${ }^{32}$. І взагалі, подорож для автора Москові$a \partial u$ - ціла філософія життя як руху, бо життя і $є$ подорожжю від народження до смерті, де кожний рух перетворюється на знак, стає місткішим і набуває глибшого сенсу.

Соціальний хронотоп у романі тісно пов'язаний із урбаністичним. Опис Москви у романі виражає певної історіософську позицію письменника. Москва, «місто тисячі та одної катівні. Високий форпост Сходу перед завоюванням Заходу. Останнє місто Азії, від п'яних кошмарів якого панічно втікали знекровлені та германізовані монархи. Місто сифілісу та хуліганів, улюблена казка озброєних голодранців. Місто більшовицького ампіру з висотними почварами наркоматів, з таємними під'їздами, забороненими алеями, місто концтаборів, націлене в небо шпилями за-

31 М. Бахтин, Формы времени и хронотопа в романе. Очерки по исторической поэтике. Вопросы литературы и эстетики. Исследования разных лет, Москва 1975, с. 192.

32 Ю. Андрухович, Московіада, с. 213. 
кам'янілих гігантів. Населення тутешніх в'язниць могло б скласти одну 3 європейських націй. Місто гранітних вензелів та мармурового колосся і п’ятикутних зірок завбільшки із сонце. Воно вміє тільки пожарити, це місто забльованих подвір'їв і перекошених дощаних парканів у засипаних тополиним пухом провулках із деспотичними назвами...», на думку Ю. Андруховича, є найбільшим у світі «українським містом», у якому кожен десятий має прізвище на «енко». Але найстрашніше, що тут його земляки почали уподібнюватися своєму північному сусідові: «чомусь почали народжуватись інші українці - свиноокі, з невиразно-заокругленими пицями, з безбарвним волоссям, яке існує тільки для того, щоб вилазити. Вочевидь, природне бажання наших предків якомога швидше випнутися у великороси призвело до певних пристосуванчих мутацій» ${ }^{33}$.

У цій країні усі просмерділися несвободою: «Імперія міняла свою зміїну шкіру, переглядала звичні тоталітарні уявлення, дискутувала, імітувала зміну законів та життєвого укладу, імпровізувала на тему ієрархії вартостей. [...] треба цій землі дати спочинок від іiі злочинної столиці» ${ }^{34}$.

Ще філософ Георг Зіммель відзначав, що всі міста мають єдину духовну сутність - ритм життя і психоемоційний фон. Про те, яким бачить автор цей психологічний стан міста, говорить чи не кожна сторінка роману, позаяк навіть міський пейзаж, який є однією з характеристик урбаністичного хронотопу, змальований у песимістичних, похмурих барвах, безкінечна злива і розчарування. Вся Москва постає імперією 3 «людом, який п'ється чергою поміж огидних ампірних колон, сичить по кутках і навколо столиків, пахне псятиною і тішиться земним існуванням ${ }^{35}$.

Москва як мегаполіс пострадянської епохи перестає бути центром загального єднання і колективізму. Тепер кожен тут сам за себе, місто 3 його суєтою, проблемами, тиснявою, переповненістю провокує самотність. Як не парадоксально, але перенасиченість міста дорівнює самотності, відстороненості. Уся ця міська повсякденність робить людей безликими, одягає на них соціальні маски, нівелює індивідуальне людське Я, і таких прикладів знайшлося безліч у літературному гуртожитку, де проживає Отто фон Ф. Таким чином зовнішній, реальний простір (хронотоп міста) протиставляється внутрішньому простору творчої особистості. І щоб позбавитися від нестерпної дійсності герой змушений вводити себе в стан сп'яніння, аби хоч якось заповнити свою внутрішню порожнечу і відволіктись від реальності.

Михайло Бахтін відзначав, що хронотоп вулиці доволі тісно пов'язаний із хронотопом кризи, життєвого перелому. Вулиця - це місце, де

Там само, с. 148.

Там само, с. 131.

Там само, с. 161. 
долі багатьох людей перетинаються і переломлюються, місце, «де відбуваються події криз, падінь, воскресінь, оновлень, прозрінь, рішень, які визначають все життя людини» ${ }^{36}$.

На відміну від Малого апокаліпсису Т. Конвіцького, який є більшою мірою «польськоцентричним», «варшавоцентричним», Москва в Ю. Андруховича - це не тільки репродукція політичного і морального тиску на Україну, але й на інші, такі ж роками гноблені нації, для яких тема меншовартості є такою ж актуальною як і для всього «затоталіризованого» міжнаціонального суспільства. Автор чітко показує свою антинасильницьку, гуманну, загальнолюдську позицію: «Нас так мало, і ми такі маленькі в порівнянні з холодною космічною пусткою, що аж ніяк не можемо собі дозволити розкіш взаємної ненависті чи територіальних претензій. Тим більше, з причин партійних, національних або расових ${ }^{37}$.

Художній простір роману охоплює велике місто, чи навіть Велику Імперію, і на противагу їй, зболену душу молодого поета. Ю. Андрухович зосереджує увагу ще й на внутрішньому хронотопі свого персонажа, на його думках, свідомості, уяві і пам'яті. Звідси випливає, що часопростір моделюється через психологічні колізії та внутрішній стан суб'єкта. Це можемо побачити в кульмінаційній фарсовій, бурлескно-балаганній картині роману, де герой потрапляє на «симпозіум» мерців, представників влади різних часів імперії. Тут все відбувається позачасово та позапросторово, ніби у химерному, хаотичному світі. Герой розстрілює покійників, які уособлювали імперію, тим самим ніби звільняється від іiі нещадного впливу на його життя. 3 великою умовністю можна назвати інтелігентного героя Ю. Андруховича персонажем зі здоровою свідомістю, ознака нинішньої мистецької епохи - витворення образу розщепленого, маргінального, уніфікованого індивіда, та подеколи окреслення марних спроб протистояти руйнівним процесам, що відбуваються в свідомості цього індивіда ${ }^{38}$.

Філософське ж сприйняття соціального простору виражається в осмисленні його як простору, який «утворюється в цій павутині відношень людини до світу. Соціальний простір і $є$ саме ставлення» ${ }^{39}$. Можливо, тому автор карнавалізує розповідь, вводить химерні видіння, ремінісценції. Спорадично автор вводить у розповідь історії про вигаданого, майже бурлескного короля України Олелька II Довгорукого-Рюриковича, як репрезентацію свого ставлення до абсурдності цієї моделі світу, створеної тоталітарним режимом. Введення в розповідь історії про Олель-

\footnotetext{
36 М. Бахтин, Эпос и роман, Санкт-Петербург 2000, с. 183.

37 Ю. Андрухович, Московіада, с. 164.

38 Л. Лавринович, цит. праця, с. 78.

39 К. Бурнашов, цит. праця, с. 5.
} 
ка II, а також потрапляння героя на симпозіум мерців має щось спільне 3 так званим нульовим хронотопом, у якому і час, і простір втрачають свій сенс, «час у ньому існує увесь відразу, а простір постає як стан, в якому одночасно потенційними $\epsilon$ всі простори» ${ }^{40}$. Так постаті, які з'являються на цьому симпозіумі, акумулюють в собі певний період історії, вони є уособленням епох жорстокості, підлості, гноблення та інших нещасть, які подарував світові час їхнього правління чи діяльності.

Часопросторові координати у романі Ю. Андруховича виявляються доволі химерно, автор ніби навмисно трансформує сучасні традиційні уявлення про категорії часу та простору, дозволяє собі гратися з ними, завдяки ретроспекціям, спогадам, хаотичному розташуванню подій. Неможливо окреслити час і простір у романі в традиційному художньому вимірі, адже аналіз цих категорій ускладнюється міфологічністю роману, авторськими візіями, снами, символікою, звідси і хаотичність композиції, багатошаровий сюжет.

Психологічний образ героя, його намагання втекти від реальності, скомпрометований типом суспільства, рушійною силою якого є взаємна ненависть, від якої намагався втекти Отто фон Ф., адже всякі спроби досягти гармонії закінчувалися тим, що його гнали.

Загалом хронотоп роману є складним і багаторівневим, зважаючи на фантасмагорійні та сюрреалістичні моменти розповіді говорити про триєдність романної оповіді не можемо, на відміну від роману Малий апокаліпсис Тадеуша Конвіцького. Фантастичні деталі, оживлення мертвих, кінематографічні прийоми, як, наприклад, перемотування часу назад і розгортання сюжету за новою схемою, все це ускладнює художній хронотоп роману, роблячи його вагомим надбанням для постмодерної української прози.

Отже, бачимо, що Ю. Андрухович як письменник постмодерного світобачення, вирізняється особливим способом часопросторового зображення подій. Соціальний хронотоп $є$ ключем до пізнання психології героя і його настроїв. Категорії часу і простору у романі Московіада то перебувають у нерозривному зв'язку, то абсолютно нівелюються. Ю. Андрухович також майстер зображення внутрішнього часопростору героя. Завдяки міфічності та візійності зображення, ретроспекціям, автор дозволяє собі грати з часом та простором, провокуючи багатоваріантне прочитання свого тексту, що $є$ характерним для постмодерністів.

40 А. Темирболат, Проблема хронотопа в современной прозе, Алматы 2003, с. 32. 


\section{БІБЛІОГРАФІЯ}

Andruhovič Ûrìj. 2003. Vona robit' minule živim ì nezaveršenim. «Komentar» № 2: 4. [Андрухович Юрій. 2003. Вона робить минуле живим $і$ незавершеним. «Коментар» № 2: 4].

Andruhovič Urìj. 2006. Moskoviada. İvano-Frankìvs'k:Vid-vo LìleâNV: 430 s. [Андрухович Юрій. 2006. Московіада. Івано-Франківськ: Вид-во ЛілеяНВ].

Bahtin Mihail. 1975. Formy vremeni i hronotopa v romane. Očerki po istoričeskojpoètike. Voprosy literatury $i$ èstetiki. Issledovaniâ raznyh let. Moskva: Hudožestvennaâ literatura]. [Бахтин Михаил. 1975. Формы времени и хронотопа в романе. Очерки по исторической поэтике. Вопросы литературы и эстетики. Исследования разных лет. Москва: Художественная литература].

Bahtin Mihail. 2000. Epos i roman. Sankt-Peterburg: Azbuka. [Бахтин М. 2000. Эпос и роман. Санкт-Петербург: Азбука].

Burnašov Konstantin. 2007. Hronotop - klûč $k$ poznaniûu social'nogo prostranstva. «Vestnik Nižegorodskogo universiteta im. N.I. Lobačevskogo. Seriâ Social'nye nauki». № 2 (7): 15-19. [Бурнашов Константин. 2007. Хронотоп - ключ к познанию социального пространства. «Вестник Нижегородского университета им. Н.И. Лобачевского. Серия Социальные науки». № 2 (7): 15-19].

Čajkovs'ka Valerìâ. 2005. «Moskoviada» Û. Andruhoviča - ne liše "Malij apokalìpsis». «Vìsnik Žitomirs'kogo unìversitetu ìm. İ. Franka». Vip. 20: 59-64. [Чайковська Валерія. 2005. «Московіада» Ю. Андруховича - не лише «Малий апокаліпсис». «Вісник Житомирського університету ім. І.Франка». Вип. 20: 59-64].

Gogulâ Marina. 2016. Kolonial'na dijsnist' u romani Tadeuša Konvic'kogo «Malij Apokalipsis». «Problemi slov'ânoznavstva». Vip. 65: 110-125. [Гогуля Марина. 2016. Колоніальна дійсність у романі Тадеуша Конвіиького «Малий Апокаліпсис». «Проблеми слов'янознавства». Вип. 65: 110-125].

Grebenûk Tetâna. 2006. Motiv "Geroâ ponevoli» v narodnic'kij, modernists'kij ta postmodernists'kij paradigmah. «Ìstorično-fîlologičnij zbìrnik z regìonal'nih problem». № 15: 161-166. [Гребенюк Тетяна. 2006. Мотив «Героя поневолі» в народницькій, модерністській та постмодерністській парадигмах. «Історично-філологічний збірник з регіональних проблем». № 15: 161-166].

Gundorova Tamara. 2005. Pislâčornobil's'ka biblioteka. Ukraïns'kij literaturnij postmodern. Kiïv: Kritika. [Гундорова Тамара. 2005. Післячорнобильська бібліотека. Украӥнський літературний постмодерн. Київ: Критика].

Kiskìn Oleksìj. 2006. Urbanističnij hronotop v postmodernists'komu romanì: avtoref. dis. na zdobuttâ nauk. stupenâ kand. filol. nauk. Kiїv. [Кискін Олексій. 2006. Урбаністичний хронотоп в постмодерністському романі: автореф. дис. на здобуття наук. ступеня канд. філол. наук. Київ].

Konvìc'kij Tadeuš. 1991. Malij Apokalipsis. / Per. z pol. Û. Andruhovič. «Vsesvìt». № 12: 3-109. [Конвіцький Тадеуш 1991. Малий Апокаліпсис / Пер. 3 пол. Ю. Андрухович. «Всесвіт». № 12: 3-109].

Kopistâns'ka Nonna. 1998. Hronotop âk aspekt vivčennâ slov'âns'kogo romantizmu (na materìali zahidnoslov'âns'kih literatur u êvropejs'komu konteksti). Slov'âns'ki literaturi: Dopovidi. XII Mižnarodnij z ̈̈zd slavistìv (Krakiv, 27 serpnâ-2 veresnâ 1998). Kiїv: 57-74. [Копистянська Нонна. 1998. Хронотоп як аспект вивчення слов'янського романтизму (на матеріалі західнослов'янських літератур у європейському контексті). Слов'янські літератури: Доповіді. ХІІ Міжнародний з 'їз славістів (Краків, 27 серпня-2 вересня 1998). Київ: 57-74]. 
Lavrinovič Lìliâ. 2002. Postmodernizm v ukraïns'kìj, pol's'kij ta rosijs'kìj prozì: tipologiâ obrazu personaža. Dis. kan. filol. nauk. Luc'k. [Лавринович Лілія. 2002. Постмодернізм в украӥнській, польській та російській прозі: типологія образу персонажа. Дис. кан. філол. наук. Луцьк].

Lìpskerov Dmitrij. 2006. Sorok let Čančžoè. Moskva: Astrel'. [Липскеров Дмитрий. 2006. Сорок лет Чанчжоэ. Москва: Астрель].

Magdiš Roman. 2013. Literaturna kritika pro specifiku časoprostoru sučasnih tvorìvmandrìv. «Naukovì zapiski Harkìvs'kogo nacìonal'nogo pedagogìčnogo unìversitetu ìm. G. S.Skovorodi. Ser.: Literaturoznavstvo». Vip. 2 (2): 83-89. [Магдиш Роман. 2013. Літературна критика про специфіку часопростору сучасних творів-мандрів. «Наукові записки Харківського національного педагогічного університету ім. Г. С. Сковороди. Сер.: Літературознавство». Вип. 2 (2): 83-89].

Maksimov Aleksandr, Belâev Igor'. 2004. Celosnost' i svoboda čeloveka: monografiâ. Ekaterinburg: Izdatel'stvo Ural'skogo gosudarstvennogo universiteta. [Максимов Александр, Беляев Игорь. 2004. Целосность и свобода человека: монографія. Екатеринбург: Издательство Уральского государственного университета].

Temirbolat Alua. 2003. Problema hronotopa v sovremennoj proze: Učebnoe posobie. Almaty. [Темирболат Алуа. 2003. Проблема хронотопа в современной прозе: Учебное пособие. Алматы].

Zabužko Oksana. 2006. Pol's'ka «kul'tura» i mi, abo Malij apokalipsis Moskoviadi. Hroniki vid Fortìnbrasa. Vibrana eseïstika. Kï̈v: 308-318. [Забужко Оксана. 2006. Польська «культура» і ми, або Малий апокаліпсис Московіади. Хроніки від Фортінбраса. Вибрана есеїстика. Київ: 308-318].

Żbikowski Piotr. 1994. Apokalipsa czy rozpad totalitarnego systemu? Wśród starych i nowych lektur szkolnych. Rzeszów.

\section{A COMPONENT OF THE CHRONOTOPE IN THE NOVELS OF YURI ANDRUKHOVYCH AND TADEUSZ KONWICKI}

Summary. Time space in the novels of Yuri Andrukhovych and Tadeusz Konwicki is a multidimensional phenomenon. It has national, metaphysical, socio- and cultural-historical, individual-psychological, geographical components. In one day, Tadeusz Konwicki conveyed the public mood of the whole country for many years. Skillfully applying various techniques of the game over time: actualization of subjective memory, retrospectives and references to the historical past, memories, stretching and, conversely, compression of the time frame. It is necessary to pay attention to the chronotope with all its components, ie to the chronotopic complex, except for time and space it is the person, movement, road, purpose, character of movement. Given the potential similarity of the ideological plan and its formal expression in the novels Small Apocalypse by T. Konwicki and Moscoviada by Yu. Andrukhovych, the features of the chronotopes will also be similar. The main value and emotional load in the novels have chronotopes of thresholds, meetings and roads.

Key words: Konwicki, Andrukhovych, space-time, chronotope, prose, novel 


\section{KOMPONENT CHRONOTOPU W POWIEŚCIACH JURIJA ANDRUCHOWYCZA I TADEUSZA KONWICKIEGO}

Streszczenie. Czasoprzestrzeń w powieściach Jurija Andruchowycza i Tadeusza Konwickiego jest zjawiskiem wielowymiarowym. Posiada komponenty narodowe, metafizyczne, społeczno-kulturowo-historyczne, indywidualno-psychologiczne oraz geograficzne. Tadeusz Konwicki w ramach czasowych obejmujących jeden dzień oddaje nastroje społeczne całego kraju, trwające przez wiele lat. Umiejętnie stosuje różnorodne techniki gry z czasem: aktualizację pamięci subiektywnej, retrospekcje i odniesienia do przeszłości historycznej, wspomnienia, rozszerzanie, a także zawężanie ram czasowych. Należy zwrócić uwagę na chronotop ze wszystkimi jego elementami składowymi, poza czasem i przestrzenią, obejmującymi również osobę, ruch, drogę, cel, charakter ruchu. Biorąc pod uwagę potencjalne podobieństwo koncepcji ideowych i ich formalnego wyrażenia w powieściach Mała apokalipsa T. Konwickiego i Moscowiada J. Andruchowycza, można stwierdzić podobieństwo cech chronotopów. Zasadniczy ładunek wartości i emocji w analizowanych powieściach zawierają chronotopy progu, spotkania i drogi.

Słowa klucze: Konwicki, Andruchowycz, czasoprzestrzeń, chronotop, proza, powieść 
